\title{
ANALISIS PENENTUAN HARGA POKOK PRODUKSI DENGAN MENGGUNAKAN METODE FULL COSTING DAN VARIABLE COSTING PADA PEMBUATAN ABON IKAN
}

\author{
Nurlaila Hasmi \\ Sekolah Tinggi Ilmu Ekonomi Tri Dharma Nusantara Makassar \\ nurlailahasmi@yahoo.com
}

\begin{abstract}
Abstrak
Penelitian ini bertujuan untuk mengetahui kesesuaian metode penentuan harga pokok produksi pada PT. Prima Istiqamah Sejahtera menggunakan metode full costing dengan variable costing.Jenis penelitian yang digunakan yaitu penelitian kualitatif dengan pendekatan desktriptif komparatif.Sumber data yang digunakan dalam penelitian ini yaitu data primer dan data sekunder. Pengumpulan data primer dilakukan dengan metode survei langsung pada lokasi penelitian dengan menggunakan teknik observasi, wawancara, dan dokumentasi. Sedangkan pengumpulan data sekunder dilakukan dengan pengumpulan dan pemahaman literatur-literatur yang relevan dengan permasalahan yang dikaji untuk mendapatkan penjelasan permasalahan penelitian. Metode analisis yang digunakan yaitu deskriptif komparatif yaitu dengan menjelaskan dan membandingkan antara metode penentuan harga pokok produksi pada PT. Prima Istiqamah Sejahtera menggunakan metode full cosing dengan variable costing. Hasil penelitian menunjukkan bahwa hasil perhitungan harga pokok produksi yang dilakukan PT. Prima Istiqamah Sejahtera relatif rendah dibandingkan metode full costing dan variabel costing. Selain itu, terdapat perbedaan perhitungan harga pokok produksi abon ikan menurut PT. Prima Istiqamah Sejahtera dengan metode full costing dan variabel costing, hal ini terjadi karena adanya perbedaan pembebanan biaya.
\end{abstract}

Kata Kunci: Metode Harga Pokok Produksi, Full Costing, dan Variable Costing.

\begin{abstract}
This study aims to determine the suitability of the method of determining the cost of production at PT. Prima Istiqamah Sejahtera uses the full costing method with variable costing. This type of research is qualitative research with a comparative descriptive approach. Sources of data used in this study are primary data and secondary data. Primary data collection is done by direct survey method at the research location using observation, interview, and documentation techniques. While secondary data collection is done by collecting and understanding literature that is relevant to the problem being studied to get an explanation of the research problem. Data were analyzed using a comparative descriptive approach regression that is by explaining and comparing between the methods of determining the cost of production at PT. Prima Istiqamah Sejahtera uses the full cosing method with variable costing. The results showed that the results of the calculation of the cost of production carried out by PT. Prima Istiqamah Sejahtera is relatively low compared to the full costing method and variable costing. In addition, there are differences in the calculation of the cost of production of shredded fish according to PT. Prima Istiqamah Sejahtera with the full costing method and variable costing, this happens because of differences in the cost incurred.
\end{abstract}

Keywords: Method Cost of Production, Full Costing, and Variable Costing.

\section{PENDAHULUAN}


Setiap perusahaan pasti memiliki tujuan yang ingin dicapai, salah satunya adalah memperoleh laba yang maksimal. Perusahaan kini berorientasi pada peningkatan laba yang optimal sebagai tujuan pengembangan usahanya. Laba dapat diperoleh dari penjualan produk. Dalam penjualan produk diperlukan penentuan harga jual produk terlebih dahulu. Harga jual produk diperoleh dari harga pokok produksi ditambah dengan laba yang diinginkan perusahaan. Penentuan harga pokok produksi berhubungan dengan pengembalian modal yang telah dikeluarkan perusahaan. Untuk mendapatkan pengembalian modal yang sesuai dengan yang telah dikeluarkan, diperlukan penentuan harga pokok produksi yang sesuai.

Dalam penentuan harga pokok produksi menggunakan dua pendekatan yaitu pendekatan full costing dan variable costing. Pendekatan full costing biasanya dikenal sebagai pendekatan yang menghasilkan laporan laba rugi sedangkan pendekatan variable costing dikenal sebagai contribution approach merupakan suatu format laporan laba rugi yang mengelompokkan biaya berdasarkan perilaku biaya, dimana biaya-biaya dipisahkan menurut kategori biaya variabel dan biaya tetap dan tidak dipisahkan menurut fungsi-fungsi produksi, administrasi dan penjualan. (Mulyadi, 2010:121)

PT. Prima Istiqamah Sejahtera adalah sebuah perusahaan yang salah satu kegiatannya bergerak di bidang industri pengolahan abon ikan yang terletak di kota Makassar. Penetapan hargajual pada PT. Prima Istiqamah Sejahtera selama ini hanya dengan menghitung seluruh biaya produksi dan melihat situasi pasar dengan tingkat keuntungan yang diharapkan untuk setiap produk yaitu 40\%. Walaupun tingkat keuntungan atau laba yang diharapkan perusahaan cukup tinggi, namun masih terdapat kesulitan perusahaan dalam menentukan harga jual yang kompetitif. Hal ini disebabkan karena harga bahan baku untuk pengolahan abon ikan cukup berfluktuasi, bahkan tidak tetap dari bulan ke bulan berikutnya. Sehingga memaksa perusahaan untuk tetap menawarkan harga jual yang efisien bagi konsumen. Hal tersebut disimpulkan bahwa PT. Prima Istuqamah Sejahtera masihmenetapkan metode tradisional olehkarena itu metode full costing ataupun variable costing diperlukan untuk bisa menentukan harga pokok produksi secara akurat dan efektif. Selain itu, mengingat tingginya persaingan antar perusahaan yang sejenis maka, perusahaan harus menetapkan hasil bersaing bagi produksinya, serta diperlukan ketepatan dan kecermatan dalam menghitung dan membebankan biaya yang sesuai dengan jumlah yang telah dikonsumsi oleh setiap aktivitas pembuatan produk agar dapat memperoleh harga pokok produksi yang akurat.

Berdasarkan latar belakang di atas, dapat dilihat betapa pentingnya menggunakan metode full costing ataupun variable costing dalam perhitungan harga pokok produksi sebagai pengganti sistem tradisional yang dianggap kurang akurat lagi. Oleh karena itu, tujuan dari penelitian ini yaitu untuk mengetahui kesesuaian metode penentuan harga pokok produksi pada PT. Prima Istiqamah Sejahtera menggunakan metode full costing dengan variable costing.

\section{Harga Pokok Produksi}

Harga pokok produksi merupakan elemen penting untuk menilai keberhasilan dari perusahaan dagang maupun perusahaan manufaktur. Harga pokok produksi adalah penjumlahan seluruh pengorbanan sumber ekonomi yang digunakan untuk mengubah bahan baku menjadi sebuah produk. Harga pokok produksi menurut Mulyadi (2012: 14) yaitu sejumlah biaya yang terjadi untuk mengolah bahan baku menjadi produk jadi yang siap untuk dijual. Menurut Supriyono (2011), Harga pokok produksi adalah suatu 
pengorbanan atas biaya-biaya produksi yang dapat menghasilkan sebuah produk dalam suatu periode. Sementara Hansen dan Mowen (2013:55), menyatakan bahwa harga pokok produksi adalah pembebanan biaya yang mendukung tujuan manajerial yang spesifik. Artinya penentuan harga pokok suatu produk bergantung pada tujuan menejerial yang spesifk atau yang ingin dicapai.

\section{Biaya}

Biaya-biaya yang terjadi dalam kegiatan manufaktur disebut biaya produksi (production cost or manufacturing cost). Biaya-biaya yang timbul pada proses produksi akan mempengaruhi perubahan harga pokok produksi. Baik peningkatan maupun penurunan biaya-biaya tersebut akan mempengaruhi proses penentuan harga pokok produksi. Biaya-biaya yang biasanya akan mempengaruhi proses produksi yaitu biaya bahan baku, biaya tenaga kerja dan biaya overhead pabrik. Adapun unsur-unsur biaya produksi yaitu biaya bahan langsung adalah semua bahan baku yang membentuk bagian integral dari produk jadi dan dimasukkan secara eksplisit dalam perhitungan biaya produksi (Carter danUsry, 2014:40).

Dunia dan Wasilah (2011:24), mengklasifikasikan biaya produksi dalam tiga elemen utama sehubungan dengan produk yang dihasilkan yaitu: bahan langsung (direct material), tenaga kerja langsung (direct labor), dan overhead pabrik (factory overhead). Oleh karena itu, harga pokok produksi dapat diklasifikaikan menjadi biaya bahan baku, biaya tenaga kerja langsung dan biaya overhead pabrik.

\section{Biaya Bahan Baku}

Menurut Muchlis (2013:69), biaya bahan baku merupakan bahan yang membentuk bagian menyeluruh dari produk jadi dan dapat dibebankan atau diperhitungkan secara langsung kepada harga pokokproduk. Biaya bahan baku diklasifikasikan dalam dua kelompok yaitu biaya bahan baku langsung dan biaya bahan baku tidaklangsung.

\section{Biaya Tenaga Kerja}

Menurut Mulyadi (2015:319), tenaga kerja merupakan usaha fisik atau mental yang dikeluarkan untuk mengolah produk. Biaya tenaga kerja adalah harga yang dibebankan untuk penggunaan tenaga kerja manusia tersebut.

Menurut Mursyidi (2010:213), mengatakan bahwa Biaya tenaga kerja dapat digolongkan menjadi dua, yaitu biaya tenaga kerja langsung (direct labor), dan biaya tenaga kerja tidak langsung (indirect labor). Biaya tenaga kerja langsung merupakan biaya tenaga kerja yang langsung berhubungan dengan proses produksi, misalnya tukang dan pekerja pabrik. Sedangkan biaya tenaga kerja tidak langsung merupakan biaya tenaga kerja yang tidak langsung berhubungan dengan produksi, misalnya gaji direktur produksi, pengawas, dan administrasi produksi.

\section{Biaya Overhead Pabrik}

Biaya overhead pabrik adalah unsur biaya produksi selain biaya bahan baku langsung dan biaya tenaga kerja langsung yang dikeluarkan selama proses produksi (Komara dan Ade, 2016). Biaya overhead pabrik merupakan biaya yang paling kompleks dan tidak dapat didefinisikan pada produk jadi, maka pengumpulan biaya overhead pabrik baru dapat diketahui setelah barang pesanan selesai diproduksi. 
Menurut Majid (2013:20) biaya overhead pabrik adalah biaya-biaya yang tidak langsung dalam sebuah proses produksi dan biaya overhead pabrik umumnya dikonsumsi oleh lebih dari satu depertemen. Biaya ini timbul akibat pemakaian fasilitasfasilitas yang digunakan untuk mengolah bahan, seperti mesin, alat-alat, tempat kerja dan lain sebagainya. Biaya overhead pabrik merupakan biaya tidak langsung karena itu biaya overhead pabrik tidak dapat secara langsung dibebankan keproduk. Penentuan harga pokok produksi untuk metode harga pokok pesanan dan metode harga pokok proses harus dapat membebankan biaya overhead pabrik kepada setiap produknya.

Menurut Bustami dan Nurlela (2010: 13), Biaya overhead dapat dikelompokan menjadi beberapa elemen, yakni bahan tidak langsung (bahan pembantu atau penolong), biaya tenaga kerja tidak langsung, dan biaya tenaga kerja langsung lainnya.

\section{Metode Perhitungan Harga Pokok Produksi}

Metode perhitungan harga pokok produksi adalah cara memperhitungkan unsur biaya produksi ke dalam harga pokok produksi. Dalam memperhitungkan unsur-unsur biaya ke dalam harga pokok produksi terdapat dua pendekatan yaitu metode Full Costing dan metode Variabel Costing. Perbedaan pokok antara kedua metode tersebut terletak pada perlakuan terhadap biaya produksi yang bersifat tetap dan akan berakibat pada perhitungan harga pokok produk dan penyajian laporan laba rugi (Komara dan Ade, 2016). Sedangkan Halim et al. (2013:47), menyatakan bahwa Metode penentuan harga pokok produk adalah dengan membebankan semua biaya produksi (biaya bahan baku, biaya tenaga kerja, dan biaya overhead pabrik) baik bersifat tetap maupun variabel kepada produk atau jasa. Unsur-unsur biaya pada harga pokok produksi terdapat dua pendekatan yaitu metode full costing dan variabel costing.

\section{Metode Full Costing}

Menurut Mulyadi (2014:17), pengertian metode full costing adalah metode penentuan harga pokok produksi ke dalam harga pokok produksi, yang terdiri dari biaya bahan baku, biaya tenaga kerja langsung, dan biaya overhead pabrik, baik yang berperilaku variabel maupun tetap dengan demikian harga pokok produksi menurut full costing terdiri dari unsur biaya produksi. Sedangkan menurut Widilestariningtyas et al. (2012:16), mengatakn bahwa Full costing merupakan metode penentuan harga pokok produksi yang memperhitungkan semua unsur biaya produksi, yang terdiri dari biaya bahan baku, biaya tenaga kerja langsung, dan biaya overhead pabrik, baik variabel maupun tetap ditambah dengan biaya nonproduksi (biaya pemasaran, biaya administrasi dan umum).

\section{Metode Variable Costing}

Menurut Mulyadi (2014:18), metode variable costing adalah metode penentuan harga pokok produksi yang memperhitungkan biaya produksi yang berperilaku variabel, ke dalam harga pokok produksi, yang terdiri dari biaya bahan baku, biaya tenaga kerja langsung, dan biaya overhead pabrik variabel. Sedangkan menurut Widilestariningtyas et al (2012: 67) menyatakan bahwa variable costing merupakan metode penentuan harga pokok produksi yang hanya membebankan biaya-biaya produksi variabel saja ke dalam harga pokok produk. Metode variablecosting ini dikenal dengan nama direct costing. Biaya produksi yang bersifat tetap pada variable costing diperlakukan sebagai biaya periode akuntansi dimana biaya tersebut terjadi. 


\section{METODE PENELITIAN}

Jenis dan Sumber Data

Jenis data yang digunakan dalam penelitian ini yaitu data kualitatif dan data kuantitatif. Data kualitatif pada penelitian ini diperoleh langsung dari hasil wawancara dengan karyawan dalam PT. Prima Istiqamah Sejahtera, sedangkan data kuantitatifnya diperoleh dari data PT. Prima Istiqamah Sejahtera.Sumber data yang digunakan dalam penelitian ini yaitu data primer dan data sekunder.

\section{Metode Pengumpulan Data}

Pengumpulan data primer dilakukan dengan metode survei langsung pada lokasi penelitian dengan menggunakan teknik observasi, wawancara, dan dokumentasi. Sedangkan pengumpulan data sekunder dilakukan dengan pengumpulan dan pemahaman literatur-literatur yang relevan dengan permasalahan yang dikaji untuk mendapatkan penjelasan permasalahan penelitian.

\section{Metode Analisis}

Metode analisis dalam penelitian ini menggunakan deskriptif komparatif yaknimenjelaskan dan membandingkan antara metode penentuan harga pokok produksi pada PT. Prima Istiqamah Sejahtera menggunakan metode full cosing dengan variable costing.

\section{HASIL DAN PEMBAHASAN \\ Penentuan Harga Pokok Produksi PT. Prima Istiqamah Sejahtera}

Tujuan dan sasaran dari perusahaan adalah peningkatan laba guna dapat mempertahankan kelangsungan hidup perusahaan.Oleh karena itu salah satu tujuan perusahaan dapat tercapai jika perusahaan dapat meningkatkan pendapatan yang diperoleh dari usaha yang dikelola. Salah satu faktor yang mempengaruhi laba dari usaha yang dikelola adalah harga pokok produksi.

Harga pokok produksi adalah biaya-biaya yang dikeluarkan perusahaan dalam proses produksi. Pada PT. Prima Istiqamah Sejahtera dalam melakukan proses produksi abon ikan, Perhitungan harga pokok harus diakukan seakurat mungkin sehingga menggambarkan biaya rill yang dikeluarkan oleh pihak perusahaan. Jadi dengan informasi tersebut pihak perusahaan dapat menentukan harga jual yang tepat dan besar keuntungan yang akan diperoleh.

Komponen biaya untuk menentukan harga pokok produksi adalah biaya-biaya yang digunakan perusahaan dalam proses produksi abon ikan. Dalam perhitungan harga pokok produksi, perusahaan masih menggunakan perhitungan sederhana, yaitu menjumlahkan seluruh biaya produksi yang dianggap berpengaruh terhadap proses produksi abon ikan.

Adapun sumber daya ekonomi atau biaya-biaya yang dikeluarkan oleh perusahaan dalam proses produksi abon ikan, yaitu:

\section{Biaya Bahan Baku}

Bahan baku adalah bahan yang digunakan dalam membuat produk dimana bahan tersebut secara menyeluruh atau bahan utama yang diolah dalam proses produksi menjadi produk jadi. Perusahaan menggunakan beberapa bahan baku dalam proses produksi abon ikan tersebut. Bahan baku tersebut antara lain ikan tuna, gula pasir, 
garam, minyak goreng, merica, ketumbar, bawang merah, bawang putih, asam, lengkuas dan jahe. Sedangkan biaya bahan baku adalah pengorbanan sumber ekonomi yang harus dikeluarkan perusahaan untuk menghasilkan atau mendapatkan bahan baku tersebut atau bahan yang membentuk bagian menyeluruh pruduk jadi. Data bahanbaku yang digunakan oleh PT. Prima istiqamah sejahtera selama bulan april 2019 dapat dilihat pada tabel berikut ini:

Tabel 1: Biaya Bahan Baku PT. Prima Istiqamah Sejahtera April 2019

\begin{tabular}{|l|c|r|r|}
\hline \multicolumn{1}{|c|}{ Bahan Baku } & Kuantitas & Harga Satuan(Rp) & $\begin{array}{c}\text { Total Harga } \\
\text { (Rp) }\end{array}$ \\
\hline Ikan Tuna & $1.000 \mathrm{~kg}$ & 30.000 & 30.000 .000 \\
\hline Gula Pasir & $300 \mathrm{~kg}$ & 12.250 & 3.675 .000 \\
\hline Garam & $1 \mathrm{Bal}$ & 24.000 & 24.000 \\
\hline Minyak Goreng & $50 \mathrm{ltr}$ & 12.000 & 600.000 \\
\hline Merica & $10 \mathrm{~kg}$ & 150.000 & 1.500 .000 \\
\hline Ketumbar & $10 \mathrm{~kg}$ & 25.000 & 2.500 .000 \\
\hline Bawang Merah & $33 \mathrm{~kg}$ & 40.000 & 1.320 .000 \\
\hline Bawang Putih & $30 \mathrm{~kg}$ & 35.000 & 1.050 .000 \\
\hline Asam & $6 \mathrm{~kg}$ & 15.000 & 90.000 \\
\hline Lengkuas & $10 \mathrm{~kg}$ & 6.000 & 60.000 \\
\hline Jahe & $8 \mathrm{~kg}$ & 28.000 & 224.000 \\
\hline Serai & $10 \mathrm{~kg}$ & 19.000 & 190.000 \\
\hline Total & & $\mathbf{R p ~ 4 1 . 2 3 3 . 0 0 0}$ \\
\hline
\end{tabular}

Sumber : PT. Prima Istiqamah Sejahtera, 2019.

Berdasarkan data di atas menunjukkan bahwa biaya bahan baku milik PT. Prima Istiqamah Sejahtera yang disajikan pada bulan april 2019 sebesar Rp.41.233.000. Biaya bahan baku yang tertinggi yaitu pada ikan tuna sebagai bahan baku utama dalam proses produksi abon yaitu sebesar RP. 30.000.000. Sedangkan biaya yang terendah pada pembelian bahan baku ialah garam dengan harga Rp. 24.000 .

\section{Biaya Tenaga Kerja}

Biaya tenaga kerja merupakan balas jasa yang diberikan oleh perusahaan kepada semua karyawan yang terlibat dalam proses produksi. Dalam menjalankan usahanya, perusahaan tidak membagi proses produksinya ke dalam beberapa departemen tertentu, dimana semua proses produksi dari awal hingga akhir dikerjakan bersama-sama oleh karyawan. Proses produksi baru akan dimulai ketika seluruh bahan baku produksi sudah tersedia seluruhnya. Perusahaan mengeluarkan biaya tenaga kerja setiap bulannya yaitu sebesar Rp 11.500.000, untuk 10 karyawan tetap yang bekerja dalam proses produksi. Biaya tersebut dikeluarkan berdasarkan perhitungan perusahaan, dimana dalam seminggu biasanya para karyawan akan datang ke perusahaan 2-4 kali untuk melakukan proses produksi. Biaya tenaga kerja PT. Prima Istiqamah Sejahtera selama bulan April 2019 dapat dilihat sebagai berikut :

Tabel 2: Biaya Tenaga Kerja PT. Prima Istiqamah Sejahtera April2019

\begin{tabular}{|c|c|c|}
\hline $\begin{array}{c}\text { Upah } \\
\text { (Rp)/orang }\end{array}$ & JumlahKaryawan & Jumlah (Rp) \\
\hline 1.150 .000 & 10 & 11.500 .000 \\
\hline
\end{tabular}


Sumber : PT. Prima Istiqamah Sejahtera, 2019.

Berdasarkan tabel 2 tersebut menunjukkan bahwa Total biaya tenaga kerja PT. Prima Istiqamah Sejahtera di bulan april 2019 yaitu sebesar Rp.11.500.000 dengan jumlah karyawan 10 orang pada produksi abon ikan. upah yang diterima per orangnya yaitu sebesar Rp. 1.150.000 per bulannya.

\section{Biaya Overhead Pabrik}

Biaya overhead pabrik merupakan biaya-biaya yang dikeluarkan perusahaan selain dari biaya bahan baku dan biaya tenaga kerja dalam proses produksi. Biaya overhead pabrik perusahaan antara lain berupa biaya kemasan, biaya gas LPG, dan biaya pemasangan stiker.

\section{a. Biaya gas LPG}

Biaya gas LPG yang digunakan oleh PT. Prima Istiqamah Sejahtera merupakan biaya variabel, semakin banyak jumlah unit yang diproduksi maka semakin tinggi pula biaya gas LPG yang harus dikeluarkan oleh perusahaaan. Dalam proses produksi, perusahaan menggunakan gas LPG ukuran $3 \mathrm{~kg}$. Berdasarkan informasi yang diperoleh dari perusahaan, bahwa dalam satu kali produksi, perusahaan akan menghabiskan 10 tabung gas dengan kapasitas produksi yaitu hampir mencapai $500 \mathrm{~kg}$ ikan tuna. Karena itu, perusahaan akan menggunakan sebanyak 20 tabung gas selamasatu bulan proses produksi. Perusahaan membeli gas LPG 3 kg dengan harga Rp 18.000 per tabungnya. Data biaya gas LPG PT. Prima Istiqamah Sejahtera selama bulan april 2019 dapat dilihat dalam tabel sebagai berikut:

Tabel 3: Biaya Gas LPG PT. Prima Istiqamah Sejahtera April 2019

\begin{tabular}{|c|c|c|}
\hline Kuantitas (tabung) & Biaya per LPG (3 kg) & Total biaya \\
\hline 20 & $\operatorname{Rp} 18.000$ & $\operatorname{Rp} 360.000$ \\
\hline
\end{tabular}

Sumber : PT. Prima Istiqamah Sejahtera, 2019.

Berdasarkan tabel 3 tersebut dapat dilihat bahwa biaya gas LPG yang digunakan PT. Prima Istiqamah Sejahtera yaitu sebesar RP. 360.000.

\section{b. Biaya Kemasan}

PT. Prima Istiqamah Sejahtera dalam mengemas produknya menggunakan 3 bentuk kemasan yaitu toples ukuran besar yang akan diisi dengan abon seberat 500 gram, toples ukuran kecil diisi dengan abon seberat 250gram, dan 100gram abon dikemas dengan menggunakan plastik aluminium. Biaya kemasan yang dikeluarkan perusahaan selalu berubah-ubah, hal ini disebabkan biaya kemasan merupakan biaya variabel, yaitu biayayangbesarnya akan berubah sesuai dengan jumlah unit yang diproduksi. Perusahaan membeli kemasan produk dalam satuan lusin dan pack. Dimana untuk satu lusin toples berisi 12 unit toples, sedangkan untuk satu pack plastik aluminium berisi 50 lembar plastik aluminium. Biasanya perusahaan akan membagi rata unit produksi untuk setiap kemasan, antara abon 100 gram, 250 gram dan 500 gram yaitu masing-masing sebanyak 600 unit dengan kapasitas abon bersih sebanyak $510 \mathrm{~kg}$. Perhitungan biaya kemasan yang dikeluarkan perusahaan pada bulan april 2019 dapat dilihat sebagai berikut:

Tabel 4: Biaya Kemasan PT. Prima Istiqamah Sejahtera April 2019

\begin{tabular}{|c|c|c|c|c|}
\hline Keterangan & $\begin{array}{c}\text { Unit } \\
\text { Produksi }\end{array}$ & Kuantitas & $\begin{array}{l}\text { Harga } \\
\text { Satuan } \\
\text { (Rp) }\end{array}$ & Harga (Rp) \\
\hline Toples ukuran besar & 600 & 50 lusin & 42.000 & 2.100 .000 \\
\hline
\end{tabular}




\begin{tabular}{|l|c|c|r|r|}
\hline Toples ukuran kecil & 600 & 50 lusin & 48.000 & 2.400 .000 \\
\hline Aluminium & 600 & 12 pak & 172.000 & 2.064 .000 \\
\hline Total & \multicolumn{4}{|r|}{ Rp 6.564.000 } \\
\hline
\end{tabular}

Sumber : PT. Prima Istiqamah Sejahtera, 2019.

\section{c. Biaya Pemasangan Stiker}

Biaya pemasangan stiker adalah biaya yang yang dikeluarkan perusahaan untuk memasang merek dagang dalam produk abonnya.Biaya ini merupakan biaya overhead pabrik yang bersifat variabel. Biaya ini timbul ketika perusahaan memesan kepada pihak ketiga (pihak lain) untuk membuat stiker (merek dagang) dalam produknya.

Adapun biaya pemasangan stiker yang harus dikeluarkan oleh PT. Prima Istiqamah Sejahtera dalam produk abonnya yaitu dapat dilihat sebagai berikut:

Tabel 5: Biaya Pemasangan Stiker PT. Prima Istiqamah Sejahtera April 2019

\begin{tabular}{|l|c|c|c|}
\hline \multicolumn{1}{|c|}{ Keterangan } & Biaya satuan (RP) & Kuantitas & Total biaya \\
\hline 100gram & 500 & 600 & 300.000 \\
\hline 250 gram & 250 & 600 & 150.000 \\
\hline 500 gram & 350 & 600 & 210.000 \\
\hline Total & & Rp 660.000 \\
\hline
\end{tabular}

Sumber : PT. Prima Istiqamah Sejahtera, 2019.

Berdasarkan data di atas menunjukkan bahwa biaya pemasangan stiker yang harus dikeluarkan PT. Prima Istiqamah Sejahtera untuk bulan April 2019 yaitu sebesar Rp 660.000, kepada pihak pembuat stiker dengan harga yg berbeda tiap kemasan. Dimana pada bulan April 2019 perusahaan memproduksi abonsebanyak510 kg, sehingga menghasilkan masing-masing 600 unit untuk setiap jenis kemasan.

Harga pokok produksi perusahaan dipengaruhi oleh beberapa jenis biaya yang telah diklasifikasikan oleh perusahaan. Perhitungan harga pokok produksi yang dilakukan perusahaan yaitu dengan menjumlahkan semuah total biaya produksi, yaitu biaya bahan baku, biaya tenaga kerja, biaya overhead pabrik setiap bulannya pada saat melakukan proses produksi.

Tabel 6: Harga Pokok Produksi PT. Prima Istiqamah Sejahtera April 2019

\begin{tabular}{|l|r|r|}
\hline \multicolumn{1}{|c|}{ Jenis Biaya } & \multicolumn{2}{c|}{ Total Biaya (Rp) } \\
\hline Biaya bahan baku & & 41.233 .000 \\
\hline Biaya tenaga kerja & & 11.500 .000 \\
\hline Biaya overhead pabrik & 360.000 & \\
\hline Biaya gas LPG & 6.564 .000 & \\
\hline Biaya kemasan & 660.000 & 7.584 .000 \\
\hline Biaya Pemasangan stiker & & $\mathbf{6 0 . 3 1 7 . 0 0 0}$ \\
\hline Total biaya overhead pabrik & & $\mathbf{5 1 0}$ \\
\hline Jumlal Biaya Produksi & & $\mathbf{R p . 1 1 8 . 2 6 9}$ \\
\hline Harga Pokok produksi/Kg & \multicolumn{2}{c}{} \\
\hline
\end{tabular}

Sumber : PT. Prima Istiqamah Sejahtera, 2019.

Berdasarkan data di atas dapat dilihat bahwa total harga pokok produksi PT. Prima Istiqamah Sejahtera selama bulan April 2019 yaitu sebesar Rp 60.317.000 dan harga pokok produksi per unitnya $(\mathrm{Kg})$, yaitu sebesar Rp118.269. Total biaya tersebut 
dipengaruhi oleh biaya bahan baku, biaya tenaga kerja dan biaya overhead pabrik. Karena itu, dapat disimpulkan bahwa biaya produksi tertinggi untuk proses produksi abon ikan yaitu biaya bahan baku sebesar Rp 41.233.000, kemudian biaya terendah untuk proses produksi abon ikan yaitu biaya overhead pabrik berupa biaya gas LPG sebesar Rp 65.000.

\section{Penentuan Harga Pokok Produksi Menurut Metode Full Costing}

Full costing merupakan metode penentuan harga produksi yang memperhitungkan semua unsur biaya produksi, yang terdiri dari biaya bahan baku, biaya tenaga kerja langsung, dan biaya overhead pabrik. Namun dalam metode full costing perhitungan harga pokok produksi akan menghitung seluruh biaya yang terlibat dalam proses produksi, baik biaya yang bersifat variabel maupun biaya tetap. Metode full costing digunakan karena metode full costing sudah sesuai dengan prinsip akuntansi yang berlaku umum, sehingga dapat menjamin keakuratan informasi yang tersaji dalam laporan harga pokok produksi.Biaya-biaya yang diakui dalam perhitungan harga pokok produksi dalam metode full costing, yaitu:

\section{Biaya Bahan Baku}

Berdasarkan data yang diperoleh dari PT. Prima Istiqamah Sejahtera total biaya bahan baku pada bulan April 2019 sebesar Rp 41.233.000.

\section{Biaya Tenaga Kerja}

Adapun biaya tenaga kerja pada produksi abon di bulan April 2019 yaitu sebesar Rp 11.500.000 dengan 10 orang karyawan.

\section{Biaya Overhead Pabrik}

Biaya overhead pabrik adalah biaya-biaya yang tidak langsung dalam sebuah proses produksi dan biaya overhead pabrik dalam metode full costing dibagi menjadi 2 yaitu:

\section{a. Biaya Overhead Pabrik Variabel}

Biaya overhead pabrik variabel adalah biaya yang berubah sebanding dengan perubahan volume kegiatan. Biaya-biaya overhead pabrik variabel terdiri dari:

\section{1) Biaya listrik}

Dalam proses produksi biaya listrik yang digunakan perusahaan hanya menyisihkan sebagian biaya untuk pembayaran listriknya. Hal ini disebabkan karena penggunaan listrik untuk proses produksi dan pemakaian rumah tangga milik perusahaan menyatuh. Karena itu perusahaan hanya memperkirakan biaya setiap bulannya yang dikeluarkan untuk biaya listrik perusahaan.vAdapun biaya listrik yang dikeluarkan perusahaan setiap bualannya dihitung tetap yaitu sebesar Rp 200.000 .

\section{2) Biaya Air}

Dalam menentukan biaya air yang dikeluarkan pada proses produksi, PT. Prima Istiqamah Sejahtera hanya melakukan estimasi yaitu sebasar Rp 65.000 setiap bulannya. Biaya tersebut dianggap tetap setiap bulannya oleh PT. Prima Istiqamah Sejahtera.

\section{3) Biaya LPG}

Biaya LPG yang digunakan sebanyak 20 tabung gas selamasatu 
bulan proses produksi. Perusahaan membeli gas LPG $3 \mathrm{~kg}$ dengan harga Rp 18.000 per tabungnya dengan total biaya sebulannya yaitu Rp 360.000.

4) Biaya Kemasan

Biaya kemasan yang dikeluarkan perusahaan selama bulan April 2019 yaitu sebesar Rp 6.564.000 yang terdiri dari 3 ukuran. Ukuran kemasan yang digunakan ialah 100 gram, 250 gram, dan 500 gram.

\section{5) Biaya Pemasangan Stiker}

Adapun biaya pemasangan stiker yang dikeluarkan dalam bulan April 2019 dengan kapasitas produksi $510 \mathrm{Kg}$ yaitu sebesar Rp 660.000 yang harga tiap kemasannya berbeda-beda.

\section{b. Biaya Overhead Pabrik Tetap}

Berdasarkan data yang diterima dari perusahaan dalam menghitung harga pokok produksi abon ikan terdapat beberapa biaya yang tidak dihitung oleh perusahaan. Biaya-biaya yang diabaikan oleh perusahaan yaitu biaya pemeliharaandan biaya perawatan alat produksi, serta biaya depresiasi alat produksi. Biaya-biaya tersebut akan dihitung sebagai biaya overhead pabrik tetap. Hal ini sebabkan karena dalam metode full costing semua biaya harus diperhitungkan dalam menentukan total harga pokok produksi yang akurat, yang nantinya akan dijadikan dasar dalam penentuan harga jual.

\section{1) Biaya Pemeliharaan Dan Perawatan Alat Produksi}

Perusahaantidak pernah lupa untuk selalu memperhatikan kondisi alat-alat yang digunakan dalam proses produksi. Dalam pemeliharaan dan perawatan alat produksi perusahaan pastinya akan mengeluarkan biaya. Namun meskipun demikian, perusahaan tetap tidak memasukkan biaya pemeliharaan ke dalam biaya produksi. Hal ini disebabkan karena alat-alat produksi dalam perusahaan tidak setiap bulannya mengalami kerusakan sehingga perusahaan menganggap bahwa biaya pemeliharaan adalah biaya tak terduga. Perusahaan hanya menyisihkan biaya sebesar Rp 300.000 perbulannya untuk biaya pemeliharaan dan perawatan alatproduksi.

\section{2) Biaya Depresiasi Alat Produksi}

Selama menjalankan bisnisnya perusahaan tidak menghitung biaya depresiasi alat produksi ke dalam harga pokok produksi. Hal ini disebabkan karena perusahaan mengklasifikasikan alat produksi sebagai modal awal perusahaan. Alat-alat yang digunakan perusahaan dalam proses produksi antara lain prizer, spinner, kompor, blender, dan wajan.

Biaya depresiasi tahun 2019 digunakan untuk menghitung harga pokok produksi taksiran menurut metode full costing.Berikut ini rumus perhitungan biaya depresiasi alat produksi.

$$
\text { Biaya depresiasi per tahun : } \frac{\text { Harga Perolehan }}{\text { Umur Ekonomis }}
$$

Berdasarkan rumus perhitungan di atas, maka dapat diketahui bahwa biaya depresiasi untukmasing-masing alat produksi setiap tahunnya. Perhitungan biaya depresiasi alat- alat produksi dapat dilihat sebagai berikut:

Tabel 7: Biaya Depresiasi Alat Produksi 2019 


\begin{tabular}{|c|c|c|c|c|c|}
\hline Alat & $\begin{array}{c}\text { Harga } \\
\text { per Unit }\end{array}$ & $\begin{array}{c}\text { Jumlah } \\
\text { Unit }\end{array}$ & $\begin{array}{c}\text { Harga } \\
\text { Perolehan } \\
\text { (Rp) }\end{array}$ & $\begin{array}{c}\text { Umur } \\
\text { Ekonomis } \\
\text { (Thn) }\end{array}$ & $\begin{array}{c}\text { Biaya } \\
\text { depresiasi } \\
(\mathrm{Rp})\end{array}$ \\
\hline Freezer & 3.574 .000 & 2 & 7.148 .000 & 10 & 714.800 \\
\hline Spinner & 2.300 .000 & 2 & 4.600 .000 & 10 & 460.000 \\
\hline Kompor & 465.000 & 4 & 1.860 .000 & 5 & 372.000 \\
\hline Blender & 258.000 & 3 & 774.000 & 5 & 154.800 \\
\hline Wajan & 160.000 & 6 & 960.000 & 5 & 192.000 \\
\hline \multicolumn{2}{|c|}{ Total } & \multicolumn{4}{|c|}{ Rp 1.893 .600} \\
\hline
\end{tabular}

Sumber : Data dioleh, 2019.

Jadi untuk menghitung biaya depresiasi perbulan dari setiap jenis alat produksi yang digunakan perusahaan dapat dihitung dengan menggunakan metode garis lurus dengan rumus:

Biaya depresiasi per bulan : $\frac{\text { Biaya Depresiasi per tahun }}{12 \text { Bulan }}$

Hasil perhitungan biaya depresiasi dapat dilihat dalam tabel berikut:

Tabel 8: Biaya Depresiasi Alat Produksi April 2019

\begin{tabular}{|l|r|r|}
\hline \multicolumn{1}{|c|}{ Alat } & $\begin{array}{c}\text { Penyusutan per Tahun } \\
\text { (RP) } \\
\text { (A) }\end{array}$ & $\begin{array}{c}\text { Penyusutan per Bulan } \\
\text { (RP) } \\
\text { (A/12) }\end{array}$ \\
\hline Freezer & 714.800 & $59.566,66$ \\
\hline Spinner & 460.000 & $38.333,33$ \\
\hline Kompor & 372.000 & 31.000 \\
\hline Blender & 154.800 & 12.900 \\
\hline Wajan & 192.000 & 16.000 \\
\hline Total (dalam pembulatan) & \multicolumn{2}{r|}{ Rp157.800 } \\
\hline
\end{tabular}

Sumber : Hasil Olahan Data, 2019

Harga pokok produksi menggunakan metode full costing menghasilkan angka yang lebih tinggi. Hal ini disebabkan karena ada beberapa biaya yang tidak diperhitungkan oleh perusahaan yaitu biaya pemeliharaan dan biaya depresiasi alat produksi. Perhitungan harga pokok produksi menggunakan metode full costing dapat dilihat dalam tabel berikut ini :

Tabel 9: Harga Pokok Produksi Berdasarkan Metode Full CostingApril 2019

\begin{tabular}{|l|r|r|}
\hline \multicolumn{1}{|c|}{ Biaya Produksi } & \multicolumn{1}{c|}{ Biaya (Rp) } & Total (Rp) \\
\hline Biaya Langsung & & \\
\hline Biaya Bahan Baku & & \\
\hline Ikan tuna & 30.000 .000 & \\
\hline Gula pasir & 3.675 .000 & \\
\hline Garam & 24.000 & \\
\hline Minyak goreng & 600.000 & \\
\hline Merica & 1.500 .000 & \\
\hline Ketumbar & 2.500 .000 & \\
\hline
\end{tabular}




\begin{tabular}{|l|r|r|}
\hline Bawang merah & 1.320 .000 & \\
\hline Bawang puth & 1.050 .000 & \\
\hline Asam & 90.000 & \\
\hline Lengkuas & 60.000 & \\
\hline Jahe & 224.000 & \\
\hline Serai & 190.000 & $\mathbf{4 1 . 2 3 3 . 0 0 0}$ \\
\hline Biaya Tenaga Kerja & & \\
\hline Tenaga kerja langsung & 11.500 .000 & $\mathbf{1 1 . 5 0 0 . 0 0 0}$ \\
\hline Biaya Overhead Pabrik Variabel & & \\
\hline Listrik & 200.000 & \\
\hline Air & 65.000 & \\
\hline LPG & 360.000 & \\
\hline Kemasan & 6.564 .000 & \\
\hline Pemasangan stiker & 660.000 & \\
\hline Biaya Overhead Pabrik Tetap & & \\
\hline Biaya pemeliharaan dan biaya \\
perawatan alat produksi & 300.000 & \\
\hline Depresiasi freezer & & \\
\hline Depresiasi spinder & $39.566,66$ & \\
\hline Depresiasi kompor & $38.333,33$ & \\
\hline Depresiasi blender & 31.000 & \\
\hline Depresiasi wajan & 12.900 & \\
\hline Total Biaya Produksi & 16.000 & \\
\hline Jumlah Unit Produksi (kg) & & $\mathbf{1 5 7 . 8 0 0}$ \\
\hline Harga Pokok Produksi per kg & & \\
\hline Sumber.739.800 \\
\hline 510 \\
\hline Data 119.098 \\
\hline
\end{tabular}

Sumber : Data diolah, 2019.

Dari data yang diolah diperoleh total biaya produksi sebesar Rp. 60.739.800, hasil tersebut merupakan penjumlahan antara total biaya bahan baku sebesar Rp41.233.000, biaya tenaga kerja yaitu sebesar Rp11.500.000, dan total biaya overhead pabrik sebesar Rp. 8.006.800., serta dibagi dengan jumlah unit produksi sebanyak 510 $\mathrm{kg}$ sehingga diperoleh harga pokok produksi per unitnya $(\mathrm{kg})$ yaitu sebesar $\mathrm{Rp}$. 119.098.

\section{Penentuan Harga Pokok Produksi Menurut Metode Variabel Costing}

Variabel costing merupakan metode penentuan produksi yang hanya memperhitungkan biaya produksi yang berperilaku variabel ke dalam biaya produksi, yang terdiri dari biaya bahan baku, biaya tenaga kerja langsung, dan biaya overhead pabrik variabel.

Biaya-biaya yang diakui dalam perhitungan harga pokok produksi menggunakan metode variabel costing sebagai berikut:

1. Biaya bahan baku perusahaan yang dikeluarkan selama bulan April 2019 yaitu Rp. 41.233.000.

2. Biaya tenaga kerja langsung perusahaan sebesar Rp. 11.500 .000 dengan 10 orang karyawan pada produksi abon ikan.

3. Biaya overhead pabrik variabel perusahaan selama sebulan yaitu biaya listrik Rp.200.000, biaya air Rp. 65.000, biaya gas LPG Rp. 360.000, biaya kemasan abon 
ikan Rp. 6.564.000, dan biaya pemasangan stiker pada kemasan sebagai merek dagang Rp. 660.000.

Perhitungan harga pokok produksi menggunakan metode variable costing dapat dilihat dalam tabel berikut ini :

Tabel 10:Harga Pokok Produksi Berdasarkan Metode VariableCostingApril 2019

\begin{tabular}{|l|r|r|}
\hline Biaya Produksi & Biaya (Rp) & Total (Rp) \\
\hline Biaya Bahan Baku & & \\
\hline Ikan tuna & 30.000 .000 & \\
\hline Gula pasir & 3.675 .000 & \\
\hline Garam & 24.000 & \\
\hline Minyak goreng & 600.000 & \\
\hline Merica & 1.500 .000 & \\
\hline Ketumbar & 2.500 .000 & \\
\hline Bawang merah & 1.320 .000 & \\
\hline Bawang putih & 1.050 .000 & \\
\hline Asam & 90.000 & \\
\hline Lengkuas & 60.000 & \\
\hline Jahe & 224.000 & \\
\hline Serai & 190.000 & \\
\hline Biaya Tenaga Kerja & & $\mathbf{4 1 . 2 3 3 . 0 0 0}$ \\
\hline Tenaga kerja langsung & 11.500 .000 & \\
\hline Biaya OverheadPabrik Variabel & & $\mathbf{1 1 . 5 0 0 . 0 0 0}$ \\
\hline Listrik & 200.000 & \\
\hline Air & 65.000 & \\
\hline LPG & 360.000 & \\
\hline Kemasan & 6.564 .000 & \\
\hline Pemasangan stiker & 660.000 & \\
\hline Total Biaya Produksi & & $\mathbf{7 . 8 4 9 . 0 0 0}$ \\
\hline Jumlah Unit Produksi (kg) & & \\
\hline Harga Pokok Produksi per kg & & $\mathbf{6 0 . 5 8 2 . 0 0 0}$ \\
\hline Sur 118.788 \\
\hline
\end{tabular}

Sumber : Data diolah, 2019.

Berdasarkan tabel tersebut perhitungan harga pokok produksi dengan menggunakan metode variable costing diperoleh total biaya produksi sebesar Rp. 60.582.000, hasil tersebut merupakan penjumlahan antara total biaya bahan baku sebesar Rp41.233.000,biaya tenaga kerja yaitu sebesar Rp11.500.000, dan biaya overhead pabrik variabel Rp. 7.849.000., dibagi dengan jumlah unit produksi sebanyak $510 \mathrm{~kg}$ sehingga diperoleh harga pokok produksi per unitnya $(\mathrm{kg})$ yaitu sebesar $\mathrm{Rp}$. 118.788 .

Perbandingan Harga Pokok Produksi pada PT. Prima Istiqamah Sejahtera dengan Metode Full Costing dan Variabel Costing

Harga pokok produksi merupakan total biaya produksi yang dikeluarkan atau pengorbanan sumber daya ekonomi dalam rangka pembuatan suatu produk, dimana setiap perusahaan mengharapkan laba yang sepantasnya dalam setiap kegiatan organisasi. Harga pokok produksi dapat dijadikan tolak ukur oleh perusahaan untuk menetapkan kebijakan harga pada produknya. Karena itu, perhitungan harga pokok 
produksi sangat penting dalam sebuah perusahaan manufaktur untuk menentukan atau memperkirakan laba yang akan diperoleh.

Berikut perbandingan harga pokok produksi pada PT. Prima Istiqamah Sejahtera dengan menggunakan metode full costing dan variabel costing.

Tabel 11: Perbandingan Harga Pokok Produksi pada PT. Prima Istiqamah Sejahtera dengan metode full costing dan variabel costing

\begin{tabular}{|l|r|r|r|}
\hline \multicolumn{1}{|c|}{ Jenis Biaya } & $\begin{array}{c}\text { Metode } \\
\text { perusahaan }\end{array}$ & \multicolumn{1}{c|}{$\begin{array}{c}\text { Full } \\
\text { Costing }\end{array}$} & \multicolumn{1}{c|}{$\begin{array}{c}\text { Variable } \\
\text { Costing }\end{array}$} \\
\hline Biaya Bahan Baku & 41.233 .000 & 41.233 .000 & 41.233 .000 \\
\hline Biaya Tenaga Kerja & 11.500 .000 & 11.500 .000 & 11.500 .000 \\
\hline Biaya overhead pabrik & 7.584 .000 & & \\
\hline Biaya Overhead Pabrik Variabel & & 7.849 .000 & 7.849 .000 \\
\hline Biaya OverheadPabrik Tetap & & 157.800 & \\
\hline Total Biaya Produksi & $\mathbf{6 0 . 3 1 7 . 0 0 0}$ & $\mathbf{6 1 . 0 3 1 . 8 2 0}$ & $\mathbf{6 0 . 5 8 2 . 0 0 0}$ \\
\hline Jumlah Unit Produksi (Kg) & $\mathbf{5 1 0}$ & $\mathbf{5 1 0}$ & $\mathbf{5 1 0}$ \\
\hline Harga Pokok Produksi per Kg & $\mathbf{1 1 8 . 2 6 9}$ & $\mathbf{1 1 9 . 0 9 8}$ & $\mathbf{1 1 8 . 7 8 8}$ \\
\hline Sura
\end{tabular}

Sumber : Data diolah, 2019.

Berdasarkan hasil analisis data penelitian yang telah dilakukan menunjukkan bahwa harga pokok produksi pada bulan april 2019 menurut perusahaan sebesar Rp. 118.269 per $\mathrm{Kg}$, sedangkan harga pokok produksi dengan metode full costing sebesar Rp. 119.098per $\mathrm{kg}$ dan berdasarkan metode variable costing sebesar Rp. 118.788 per $\mathrm{kg}$, maka selisih nilai dari harga pokok produksi yaitu sebesar Rp. 829per kg dan Rp. 519.

\section{KESIMPULAN}

Berdasarkan hasil analisis dan pembahasan pada penentuan harga pokok produksi menurut perusahan dengan metode full costing dan variable costing maka penulis dapat menarik kesimpulan bahwa hasil perhitungan harga pokok produksi yang dilakukan PT. Prima Istiqamah Sejahtera relatif rendah dibandingkan metode full costing dan variabel costing, hal ini dapat dilihat dari hasil perhitungan yakni metode perusahaan sebesar Rp. 118.269 per $\mathrm{kg}$, sedangkan harga pokok produksi dengan metode full costing sebesar Rp. 119.098 per $\mathrm{kg}$ dan berdasarkan metode variable costing sebesar Rp. 118.788 per kg. Selain itu, terdapat perbedaan perhitungan harga pokok produksi abon ikan menurut PT. Prima Istiqamah Sejahtera dengan metode full costing dan variabel costing, hal ini terjadi karena adanya perbedaan pembebanan biaya. Metode perusahaan tidak memperhitungkan biaya overhead pabrik secara keseluruhan sebagai biaya produksi baik dari biaya tetap maupun biaya variabel. Sedangkan metode full costing akan membebankan semua biaya overhead pabrik. Karena itu, metode full costing lebih besar dibandingkan metode perusahaan dan metode variabel costing.

\section{SARAN}

Berdasarkan kesimpulan yang telah dikemukakan tersebut, maka penulis menyarankan agar perusahaan sebaiknya menggunakan metode harga pokok produksi sesuai yang selama ini digunakan oleh perusahaan. Alasannya metode full costing maupun variable costing, memiliki hasil perhitungan harga pokok yang lebih tinggi dari pada yang digunakan oleh perusahaan. Dengan kata lain, tujuan utama dari perusahaan 
secara principal terlah tercapai. Meskipun, adanya item biaya yang bisa saja menyebabkan munculnya persepsi laba semu akibat tidak nampaknya item biaya tertentu pada BOP.

\section{DAFTAR PUSTAKA}

Bustami, B \& Nurlela. (2010). Akuntansi Biaya. Graha Ilmu, Yogyakarta.

Carter, W. K., \& Usry, M. F. (2014). Akuntansi Biaya. Diterjemahkan oleh Krista. Buku 1. Edisi 14. Salemba Empat, Jakarta.

Dunia, Firdaus Ahmad \& Wasilah Abdullah. (2011). Akuntansi Biaya. Salemba Empat, Jakarta.

Halim, A. et al. (2013). Akuntansi Manajemen: Akuntansi Manajerial, Edisi Kedua. $B P F E$, Yogyakarta.

Hansen, Dor R \& Maryanne M Mowen. (2013). Akuntansi Manajerial. Salemba Empat, Jakarta.

Komara, B \& Ade S. (2016). Analisis Penentuan Harga Pokok Produksi dengan Metode Full Costing sebagai Dasar Penetapan Harga Jual pada CV Salwa Meubel. Jurnal Ilmia Ilmu Ekonomi, Vol.5, Edisi 9.

Majid, Jamaluddin. (2013). Memahami Akuntansi Manajemen. Alauddin University Press, Makassar.

Manein, Jenita Olviana. et al. (2020). Penentuan Harga Pokok Produksi dengan menggunakan Metode Full Costing pada Pembuatan Rumah Kayu. Indonesia Accounting Journal, Vol.2, Number 1.

Muchlis, Saiful. (2013). Akuntansi Biaya Kontemporer. Alauddin University Press, Makassar.

Mulyadi. (2010). Akuntansi Biaya, Edisi 5. Badan Penerbit Sekolah Tinggi Ilmu Manajemen, Yogyakarta.

Mulyadi. (2012). Akuntansi Biaya. Edisi kelima. Unit Penerbit dan Percetakan Akademi Manajemen Perusahaan YKPN, Yogyakarta.

Mulyadi. (2014). Sistem Akuntansi, Cetakan Keempat. Sekolah Tinggi Ilmu Manajemen $Y K P N$, Yogyakarta.

Mulyadi. (2015). Akuntansi Biaya, Edisi Lima. Bagian Penerbitan Sekolah Tinggi Ilmu Manajemen YKPN, Yogyakarta.

Mursyidi. (2010). Akuntansi Biaya. PT. Refika Aditama, Bandung. 

AkMen
Volume 17 Nomor 2 Juni 2020
Hal.254-269
e-ISSN : 2621-4377 \& p-ISSN : 1829-8524
Homepage: https//e-jumal.stienobel-indonesiaacid/index.php/akmen

Supriyono. (2011). Akuntansi Biaya: Pengumpulan Biaya dan Penentuan Harga Pokok, Edisi kedua, Cetakan kelima belas. BPFE, Yogyakarta.

Widilestariningtyas. et al. (2012). Akuntansi Biaya, Edisi Kesatu. Graha Ilmu, Yogyakarta. 